\title{
Degradation of Poly( $\varepsilon$-caprolactone) by a Thermophilic Community and Brevibacillus thermoruber Strain 7 Isolated from Bulgarian Hot Spring
}

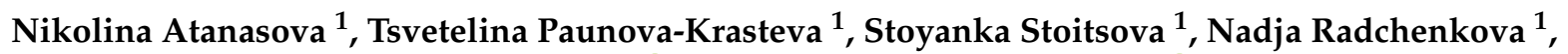 \\ Ivanka Boyadzhieva $^{1}$, Kaloyan Petrov ${ }^{2}$ (D) and Margarita Kambourova ${ }^{1, * \mathbb{D}}$
}

1 Institute of Microbiology, Bulgarian Academy of Sciences, Acad. G. Bonchev Str. Bl. 26, 1113 Sofia, Bulgaria; nikolina@microbio.bas.bg (N.A.); pauny@abv.bg (T.P.-K.); stoitsova_microbiobas@yahoo.com (S.S.); nstoicheva@yahoo.com (N.R.); petrovaim@abv.bg (I.B.)

2 Institute of Chemical Engineering, Bulgarian Academy of Sciences, Acad. G. Bonchev Str. Bl. 103, 1113 Sofia, Bulgaria; kaloian04@yahoo.com

* Correspondence: margikam@microbio.bas.bg

\section{check for}

updates

Citation: Atanasova, N.;

Paunova-Krasteva, T.; Stoitsova, S.;

Radchenkova, N.; Boyadzhieva, I.;

Petrov, K.; Kambourova, M.

Degradation of Poly( $\varepsilon$-caprolactone) by a Thermophilic Community and Brevibacillus thermoruber Strain 7 Isolated from Bulgarian Hot Spring. Biomolecules 2021, 11, 1488. https:// doi.org/10.3390/biom11101488

Academic Editor: Marisa P. Sárria

Received: 5 September 2021

Accepted: 7 October 2021

Published: 9 October 2021

Publisher's Note: MDPI stays neutral with regard to jurisdictional claims in published maps and institutional affiliations.

Copyright: (c) 2021 by the authors. Licensee MDPI, Basel, Switzerland. This article is an open access article distributed under the terms and conditions of the Creative Commons Attribution (CC BY) license (https:/ / creativecommons.org/licenses/by/ $4.0 /)$.
Abstract: The continual plastic accumulation in the environment and the hazardous consequences determine the interest in thermophiles as possible effective plastic degraders, due to their unique metabolic mechanisms and change of plastic properties at elevated temperatures. PCL is one of major biodegradable plastics with promising application to replace existing non-biodegradable polymers. Metagenomic analysis of the phylogenetic diversity in plastic contaminated area of Marikostinovo hot spring, Bulgaria revealed a higher number taxonomic groups (11) in the sample enriched without plastic (Marikostinovo community, control sample, MKC-C) than in that enriched in the presence of poly- $\varepsilon$-caprolactone (PCL) (MKC-P), (7). A strong domination of the phylum Proteobacteria was observed for MKC-C, while the dominant phyla in MKC-P were Deinococcus-Thermus and Firmicutes. Among the strains isolated from MKC-P, the highest esterase activity was registered for Brevibacillus thermoruber strain 7 at $55{ }^{\circ} \mathrm{C}$. Its co-cultivation with another isolate resulted in $\sim 10 \%$ increase in enzyme activity. During a 28-day biodegradation process, a decrease in PCL molecular weight and weight loss were established resulting in 100\% degradation by MKC-P and 63.6\% by strain 7. PCL degradation intermediate profiles for MKC-P and pure strain were similar. Broken plastic pieces from PCL surface and formation of a biofilm by MKC-P were observed by SEM, while the pure strain caused significant deformation of PCL probes without biofilm formation.

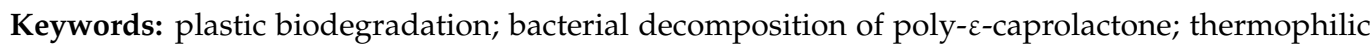
PCL degrading community; Brevibacillus thermoruber; microbial biofilm

\section{Introduction}

Plastic's invasive entrance in human life notably improved its standard, making it easier, safer, and more colorful. Due to their exclusive properties, such as bio-inertia, resistance to environmental influence and microbial action, easy manufacturing, light weight, and low production cost, everyday plastic use shows an exponentially increasing trend for production and consumption. Synthetic plastics are widely used in the global economy, with an annual worldwide production at a scale of 350 to 400 million metric tons [1]. However, due to their nature of solid and densely cross-linked polymers, they are not easily accessible for microbes and enzymes. In the category of biodegradable polyesters, poly-e-caprolactone (PCL) is among the highly attractive compounds. For the forecast period 2019-2027, an annual growth of $11.2 \%$ is envisaged, reaching US\$ 214.2 million by the end of 2021 and 402.7 million by an end of 2027 [2]. Europe and North America are expected to remain dominant regions throughout the period 2020-2030 with a market share close to $60 \%$. Among other economies around the world, the COVID-19 pandemic has impacted the functioning of the global polycaprolactone market space [3]. 
Poly- $\varepsilon$-caprolactone $\left(\mathrm{C}_{6} \mathrm{H}_{10} \mathrm{O}_{2}\right) \mathrm{n}$ is derived from the chemical synthesis of a crude oil prepared by ring-opening polymerization of $\varepsilon$-caprolactone and 2-methylene-1-3dioxepane. It is semi-crystalline polyester whose crystallinity decreases with an increase in its molecular weight. PCL is characterized by a low melting point of around $60{ }^{\circ} \mathrm{C}$ and a glass transition temperature of about $-60^{\circ} \mathrm{C}$. It possesses exceptional properties such as good hydrophobic characteristics, chemical, UV-, and wear resistance, low temperature flexibility, gloss, and adhesion. PCL-based products are an effective solution for different healthcare applications due to their non-toxic and non-hazardous nature, good biocompatibility and biodegradability [4]. They have numerous applications as elastic biomaterials, such as implants, orthopedic, surgical drapes, general-purpose tubing, drug delivery, wound dressing, suture, injection-molded devices, etc. The possibility for an extrusion of PCL filaments with an accurate diameter is of growing importance in 3-D printing technology due to its stable melting point and no bubble formation. PCL dentistry application includes dental splints and root canal filling. It is a preferable plastic in making automotive components, construction materials, packaging, jewelry, models, prototyping, hot-melt glue and laminating pouches. PCL-based polyurethanes are widely used in coatings, adhesives, sealants, and elastomers. Currently, PCL is still not a cost-effective polymer with a USD $6-8 / \mathrm{kg}$ market price. Great efforts have been focused on mass production at lower costs.

Biodegradation is a process of decomposition of a large polymer molecule by microorganisms to oligomers that could be utilized as a sole source of carbon and energy. Unlike the high biodegradability of the natural plastics, the synthetic polymers have a low biodegradability rate [5-7]. Although PCL refers to the group of biodegradable plastics, the reports on its biodegradation have shown that it is still a slow process. Several fungi, such as Penicillium funiculosum, Aspergillus flavus, Rhizopus delemar, R. arrizus, and Candida cylindracea [8] and bacteria such as Tenacibaculum, Alcanivorax and Pseudomonas [9], Alcaligenes faecalis [10], Bacillus pumilus [11], and Clostridium acetobutylicum [12] have been reported as PCL degraders.

According to Pinto et al. [13] the nature of the degrading organisms is among the most important factors for an effective biodegradation, together with the abiotic types of plastic and the physicochemical conditions. Biodegradation is assumed to occur in the amorphous phase of plastic polymers [14,15]. The molecules in the amorphous region are not able to move significantly at lower temperatures, suggesting a higher efficiency of thermophilic processes in which the polymer chains can gain enough mobility to access the enzyme active sites [16,17]. The changes seen in the plastic's properties at an elevated temperature suggest improved bioavailability and solubility [14]. Thermophilic processes are characterized by a higher enzyme turnover rate as a result of the decreased polymer strength at enhanced temperatures, high diffusion rates of organic compounds, decreased viscosity of culture liquids, and reduced risk of microbial contamination. Several thermophiles have been reported as plastic degraders. They mainly belong to a bacilli group, such as the polyethylene degraders Bacillus sp. BCBT21 and Brevibaccillus borstelensis strain 707 [18,19], nylon 6 and 12 degraders Anoxybacillus rupiensis and Geobacillus thermocatenulatus [20,21]. Information concerning thermophilic PCL degradation is very limited and concerns only representatives of the genus Streptomyces [22,23]. Still, thermophilic bacilli able to degrade PCL are not known [24].

In the present paper, we report an effective PCL degradation at $55{ }^{\circ} \mathrm{C}$ by a microbial community from the Marikostinovo hot spring (MKC), Bulgaria and an isolation of Brevibacillus thermoruber strain 7 with an esterase activity.

\section{Materials and Methods}

\subsection{Sample Collection and Culture Enrichment}

Pooled samples containing plastic debris and water in the vicinity of plastic wastes were collected from five Bulgarian hot springs located in south-west Bulgaria: Rupi $\left(41.45857^{\circ} \mathrm{N}, 23.26209^{\circ} \mathrm{E}\right)$, Levunovo $\left(41.4872^{\circ} \mathrm{N}, 23.3055^{\circ} \mathrm{E}\right)$, Marikostinovo $\left(41.4314^{\circ} \mathrm{N}\right.$, 
23.3335 $\mathrm{E}$ ), Simitli $\left(41.8897^{\circ} \mathrm{N}, 23.1060^{\circ} \mathrm{E}\right)$, and Dolno Osenovo $\left(41.9544^{\circ} \mathrm{N}, 23.2413^{\circ} \mathrm{E}\right)$. The temperature of the sites varied from 55 to $72{ }^{\circ} \mathrm{C}$, with a $\mathrm{pH}$ in the range 7.1 to 8.8. Marikostinovo water characteristics were $57^{\circ} \mathrm{C}, \mathrm{pH} 7.3$, low dissolved-mineral content $(1031 \mathrm{mg} / \mathrm{L})$ with a mineral composition $(\mathrm{mg} / \mathrm{L}): \mathrm{F}^{-}, 8.4 ; \mathrm{Cl}^{-}, 18 ; \mathrm{SO}_{4}{ }^{2-}, 227 ; \mathrm{HCO}_{3}{ }^{-}, 412$; $\mathrm{SiO}_{3}{ }^{2-}, 77 ; \mathrm{Na}^{+}, 250 ; \mathrm{Ca}^{2+}, 23 ; \mathrm{Mg}^{2+}, 6$. The samples were transferred to the laboratory in sterile glass bottles kept in a thermostat bag and $2 \mathrm{~g}$ plastic waste and $2 \mathrm{~mL}$ water used as inocula for enrichment in $20 \mathrm{~mL}$ basal medium containing: $\mathrm{NH}_{4} \mathrm{NO}_{3}, 0.01 \% ; \mathrm{KH}_{2} \mathrm{PO}_{4}$, $0.03 \% ; \mathrm{K}_{2} \mathrm{HPO}_{4} 0.14 \% ; \mathrm{MgSO}_{4}, 0.01 \% ; \mathrm{FeSO}_{4} \cdot 7 \mathrm{H}_{2} \mathrm{O}, 0.002 \% ; \mathrm{Na}_{2} \mathrm{MoO}_{4} \cdot 2 \mathrm{H}_{2} \mathrm{O}, 0.0005$; yeast extract, $0.1 \%$. As an only carbon source poly( $\varepsilon$-caprolactone) pearls, average Mw 80,000 (Sigma-Aldrich, Steincheim am Albuch, Germany) and a diameter ranged from 2.9 to $4.8 \mathrm{~mm}$ were used. PCL pearls were sterilized separately by three hours soaking in $96 \%$ ethanol and five minutes sonication at room temperature. They were added to the basal medium at a final concentration of $0.3 \pm 0.02 \%$. The cultivation was performed at $55^{\circ} \mathrm{C}$, $80 \mathrm{rpm}$ for $72 \mathrm{~h}$. The control flasks did not contain PCL. Growth (OD660) and esterase activity in the supernatant were monitored daily.

\subsection{Microbial Community Analysis}

Microbial composition of Marikostinovo community after cultivation in a basal medium without plastic (MKC-C) and in the presence of $0.3 \%$ PCL (MKC-P) was determined after 5 days-cultivation. After centrifugation of $200 \mathrm{~mL}$ culture liquid the pellet was sent to Eurofins Genomics Europe, Ebersberg, Germany for a metagenomic analysis. DNA was extracted with a commercial kit according to the manufacturer's manual. $16 \mathrm{~S}$ targets were PCR amplified from DNA extracts using target specific NGS primers and analyzed by Amplicon sequencing on the Illumina MiSeq platform. During the bioinformatics analysis sequences were sorted into sequence sets according to their similarity. Each set was represented by a master sequence. Comparison of each master sequence with entries in the nucleotide collection of the US National Center for Biotechnology Information, NCBI provided the taxons present in the samples. Taxons with a fraction of at least $0.1 \%$ of all assigned reads were reported.

\subsection{Isolation of Pure Strains and Screening of Isolates}

An MKC-P sample was spread on rich medium agar plates containing $0.2 \%$ peptone; $0.1 \%$ yeast extract; $0.1 \%$ glucose; $2 \%$ agar. The mixed cultures streaked at least three times for an isolation of pure strains and single colonies with a different appearance were selected for further work. The screening procedure for PCL degrading bacteria was performed as previously described [25] with some modifications. An emulsion of 1\% PCL with average Mw 14,000 (Sigma-Aldrich, Steincheim am Albuch, Germany) in acetone was prepared on magnetic stirrer at $50{ }^{\circ} \mathrm{C}$. Twenty $\mathrm{mL}$ of the emulsion were added through a sterile filter to the sterile basal medium supplemented with $2 \%$ agar. The magnetic stirring at $50{ }^{\circ} \mathrm{C}$ continued until acetone evaporated and the medium was poured into plates. One loop of each strain culture was placed on the agar surface and incubation continued for $24 \mathrm{~h}$ at $55^{\circ} \mathrm{C}$. Biodegradation activity was determined by the formation of clear halos around the growth spots.

\subsection{Phylogenetic Characterization of the Isolated Bacteria}

Petri dishes containing the screened pure strains were sent for phylogenetic characterization in Macrogen Europe BV, Amsterdam, Netherland where the full length 16S rRNA gene sequences were retrieved by using universal bacterial primers $27 \mathrm{~F}$ and $1492 \mathrm{R}$. Sequence length for all isolates was $>1440 \mathrm{bp}$. They were aligned to organisms present in the Gene Bank database on 15 April 2021 using the Basic Local Alignment Search Tool (BLAST, https://blast.ncbi.nlm.nih.gov/Blast.cgi?PROGRAM=blastn\&PAGE_TYPE= BlastSearch\&LINK_LOC=blasthome, accessed on 29 January 2021 and 15 April 2021). Their DNA sequences accession numbers were MW541894 to MW541896 and MW927322 to MW927332. 


\subsection{Optimization of the Parameters for PCL Degradation}

The effect of $\mathrm{pH}$ on the ability of the MKC-P, B. thermoruber strain 7, and co-culture of strain 7 and strain 2 to degrade PCL as a sole carbon source was investigated by the commonly used in PCL degradation esterase assay in pH range $6-9(0.5$ interval $)$ at $55^{\circ} \mathrm{C}$. Cultures were incubated in the basal medium for $72 \mathrm{~h}$ on a shaker $(80 \mathrm{rpm})$ at $55^{\circ} \mathrm{C}$. The optimum $\mathrm{pH}$ value was employed in the experiment for evaluation of the temperature effect on PCL degradation. The temperature dependence of PCL was followed at 50, 55, 60 , and $65{ }^{\circ} \mathrm{C}$. A control of an uninoculated culture medium with PCL was run at all temperatures. The influence of PCL concentration in the medium on the esterase activity was followed at $0.1,0.3,0.5$, and $0.7 \%(w / v)$.

\subsection{Esterase Assay}

As PCL represents a polyester, esterase assay was used for an estimation of enzyme activity. It was measured in the supernatant after centrifugation of the culture liquid at $4000 \times \mathrm{g}$ for $15 \mathrm{~min}$. Hydrolysis of p-nitrophenyl palmitate (p-NPP) as a substrate was determined spectrophotometrically as described previously [26] at $55^{\circ} \mathrm{C}$ in $0.05 \mathrm{M}$ sodium phosphate buffer, pH 7.8 at $405 \mathrm{~nm}$. One unit of esterase activity was determined as the amount of enzyme needed to liberate $1 \mu \mathrm{M}$ p-nitrophenol per minute in the described conditions. A molar extinction coefficient for $\mathrm{p}$-nitrophenol at $\mathrm{pH} 7.8$ was found to be $3.39 \times 10^{3} / \mathrm{M}$.

\subsection{Estimation of the Bacterial Biomass}

It was impossible to use standard methods for the estimation of a bacterial growthlike measurement of optical density or microscopic counting due to the formation of visible biofilms on the surface of the PCL pearls during the 4-week biodegradation process in MKC-P. This is why the microbial growth was evaluated by measuring the protein concentration in the culture liquid and in the cells removed from PCL surface after SDS treatment. Colonized PCL pearls taken from the bacterial liquid culture were washed with water and then treated with $2 \%$ SDS at $40{ }^{\circ} \mathrm{C}$ for $4 \mathrm{~h}$. The procedure was repeated, and the cells were harvested by centrifugation. Furthermore, they were washed in $0.06 \mathrm{M}$ potassium phosphate buffer ( $\mathrm{pH} 7.8$ ) and suspended in five-times their wet volume of the same buffer. The suspension cells were disrupted in an IsoLab sonicator at $40 \mathrm{kHz}$ frequency for two periods of $5 \mathrm{~min}$ at room temperature. Cell debris were removed by centrifugation at $12,000 \times \mathrm{g}$ for $10 \mathrm{~min}$ and protein content in the resultant supernatant determined by the method of Lowry et al. [27], with bovine serum albumin as a standard. The esterase activity in both supernatant and cell debris suspension was also determined.

\subsection{Estimation of the Gravimetric Weight}

PCL biodegradation was determined by the gravimetric method for 4 weeks using a balance with $10 \mu \mathrm{g}$ accuracy. The initial weight of PCL pearls in all flasks was $150 \pm 9 \mathrm{mg}$, and the weight loss was calculated each week for three of the flasks. The culture medium was changed weekly in the flasks, in which the weight was not determined. To assure accurate measurement of the residual weight of the pearls, the bacterial biofilm was removed from PCL surface by $2 \%(v / v)$ SDS as described above. The pearls were washed with water and ethanol and dried on a filter paper overnight at $50{ }^{\circ} \mathrm{C}$. The weight loss of PCL pearl weight per day (degradation rate) was calculated on the base of their gravimetric weight loss according to the formula: $\mathrm{DR}=\left(\mathrm{W}_{0}-\mathrm{W}\right) / 7$ [18], where $\mathrm{DR}$ is the degradation rate, $\mathrm{W}_{0}$ is the PCL pearl weight at the end of the previous week (mg), and $\mathrm{W}$ is the retention pearl weight at the end of the current week. Three flasks were used for each week measurement and average weight change was estimated. The standard error (SE) calculated from data deviation was $8 \%$. 


\subsection{Gel Permeation Chromatography}

GPC analysis was performed in the different stages of the degradation process with Mw 14,000 PCL. Supernatant ( $3 \mathrm{~mL}$ ) was frozen in $30 \mathrm{~mL}$ glass vial at $-15^{\circ} \mathrm{C}$ and kept in lyophilic dryer at $-60^{\circ} \mathrm{C}$ with $80 \mathrm{mTor}$ vacuum for $12 \mathrm{~h}$. The sample was dissolved in $1 \mathrm{~mL}$ HPLC grade tetrahydrofuran (THF) for $2 \mathrm{~h}$ at $45^{\circ} \mathrm{C}$. The sample was filtered through $0.45 \mu \mathrm{m}$ PTFE syringe filter in standard $2 \mathrm{~mL}$ chromatography vials. A GPC analyzer (Model SHIMADZU Nexera) (Shimadzu, Kyoto, Japan) equipped with 5-Channel Degasser DGU-20A, HPLC Pump LC-20AD, Autosampler SIL-20AC, Column Oven CTO-20AC, and Refractive Index Detector RID-20A was operated at $45^{\circ} \mathrm{C}$ and a THF elution rate of $1.0 \mathrm{~mL} / \mathrm{min}$. The GPC Column Set PSS SDV $50 \AA$ ( $300 \mathrm{~mm} \times 8.00 \mathrm{~mm} \times 5 \mu \mathrm{m})$, PSS SDV $100 \AA$ (300 mm $\times 8.00 \mathrm{~mm} \times 5 \mu \mathrm{m})$, PSS SDV Linear M $(300 \mathrm{~mm} \times 8.00 \mathrm{~mm} \times 5 \mu \mathrm{m})$ were used. Shimadzu, Kyoto, Japan)

\subsection{Scanning Electron Microscopy (SEM)}

MKC-P and the selected strain were inoculated into $20 \mathrm{~mL}$ of basal medium with $0.3 \%$ PCL as a sole carbon source. Cultivation was performed for $72 \mathrm{~h}$ or 3 weeks. Control samples were processed in parallel, in the absence of bacteria. The samples were fixed for $2 \mathrm{~h}$ in $4 \%$ glutaraldehyde in $0.1 \mathrm{M} \mathrm{Na}$ cacodylate buffer ( $\mathrm{pH} 7.2$ ), then washed and post-fixated in $1 \%$ OsO4 for $1 \mathrm{~h}$. Dehydration was performed in graded ethanol series. After sputter-coated with gold using Edwards's sputter coater, the samples were examined by SEM (Philips scanning electron microscope, Phillips, Amsterdam, The Netherlands), at accelerating voltage $30 \mathrm{kV}$.

\section{Results}

\subsection{Phylogenetic Diversity in Samples Cultivated with and without Plastic}

An esterase activity of pooled samples collected from five Bulgarian hot springs and enriched in a basal medium with PCL was registered in two of the samples, from Levunovo $(54.83 \mathrm{U} / \mathrm{mL})$ and from Marikostinovo $(174.9 \mathrm{U} / \mathrm{mL})$. The highest activity for both samples was reached after $48 \mathrm{~h}$ of cultivation and did not change during the week of the experiment. Marikostinovo community (MKC) was selected for further work. Metagenomic analysis revealed that the community composition in the control that did not contain plastic (MKC-C) (Table 1 and Figure 1A) was characterized by a higher diversity (11 phylogenetic groups, 5 orders) and a strong domination of the phylum Proteobacteria $(81.2 \%)$, mainly Betaproteobacteria $(77.2 \%)$. Other represented phyla were DeinococcusThermus (15.5\%) and Firmicutes (2.3\%). Representatives of Archaea were not identified. Community composition in the presence of PCL (MKC-P) (Table 2 and Figure 1B) was characterized by a limitation of the community diversity (7 phylogenetic groups, 3 orders) and a strong domination of the phyla Deinococcus-Thermus (65.6\%) and Firmicutes, Class Bacilli (30.7\%). The increase in the order Bacillales share was more than thirteen-fold and of Deinococcus-Thermus more than four-fold. Appearance of noticeable fractions of Meiothermus (58.1\%) and Brevibacillus (18.5\%) could suggest their active participation in PCL degradation. Sharp decrease of Proteobacteria reads represented by one species, Elioraea tepidiphila (3.7\%) was observed. Two community metagenomes were deposited in NCBI by BioProject accession number PRJNA766622 (https:/ / www.ncbi.nlm.nih.gov/sra/ PRJNA766622, accessed on 29 September 2021).

Table 1. Taxonomic groups identified in MKC-C.

\begin{tabular}{|c|c|c|}
\hline Identified Group & Phylogenetic Level & Reads, \% \\
\hline Caldimonas sp. & $\begin{array}{l}\text { Phylum Proteobacteria, } \\
\text { Order Burkholderiales }\end{array}$ & 42.2 \\
\hline Tepidimonas ignava & $\begin{array}{l}\text { Phylum Proteobacteria, } \\
\text { Order Burkholderiales }\end{array}$ & 21.0 \\
\hline Meiothermus sp. & $\begin{array}{c}\text { Phylum Deinococcus-Thermus, } \\
\text { Order Thermales }\end{array}$ & 14.5 \\
\hline
\end{tabular}


Table 1. Cont.

\begin{tabular}{ccc}
\hline Identified Group & Phylogenetic Level & Reads, \% \\
\hline Tepidimonas sp. & $\begin{array}{c}\text { Phylum Proteobacteria } \\
\text { Order Burkholderiales } \\
\text { Phylum Firmicutes, } \\
\text { Order Bacillales }\end{array}$ & 13.7 \\
Thermomonas sp. & $\begin{array}{c}\text { Phylum Proteobacteria, } \\
\text { Order Xanthomonadales } \\
\text { Elioraea tepidiphila }\end{array}$ & 2.3 \\
Thermaceae & $\begin{array}{c}\text { Order Rhodospirillales } \\
\text { Phylum Deinococcus-Thermus, } \\
\text { Order Thermales } \\
\text { Roseomonas }\end{array}$ & 1.5 \\
& $\begin{array}{c}\text { Class Alphaproteobacteria } \\
\text { Order Rhodospirillales } \\
\text { Family Acetobacteraceae }\end{array}$ & 1.1 \\
Acetobacteraceae & $\begin{array}{c}\text { Class Alphaproteobacteria } \\
\text { Order: Rhodospirillales }\end{array}$ & 0.9 \\
Burkholderiales & Phylum Proteobacteria & 0.5 \\
\hline
\end{tabular}

A

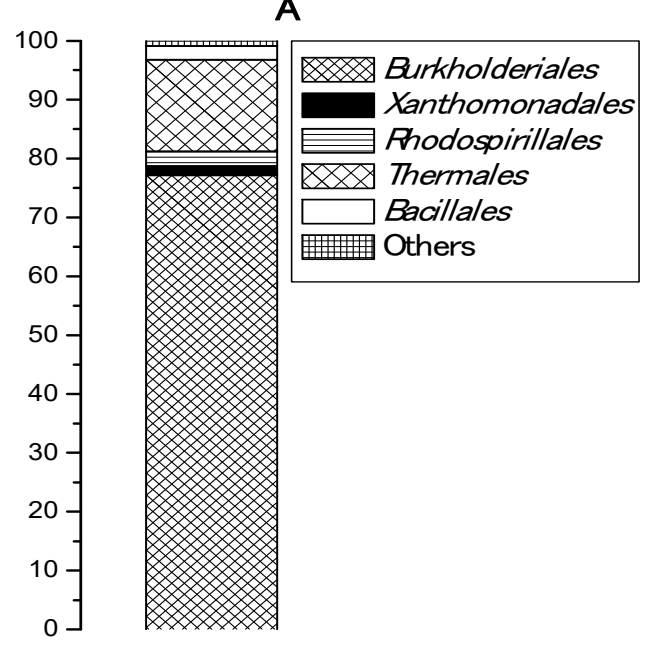

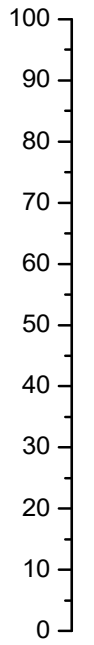

B

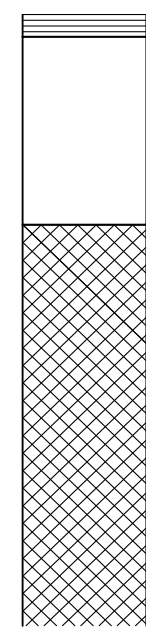

Figure 1. Bacterial orders represented (\%) in: (A), MKC-C; (B), MKC-P.

Table 2. Taxonomic groups identified in MKC-P.

\begin{tabular}{|c|c|c|}
\hline Identified Group & Phylogenetic Affiliation & Reads (\%) \\
\hline Meiothermus & $\begin{array}{c}\text { Phylum Deinococcus-Thermus, Order } \\
\text { Thermales }\end{array}$ & 58.1 \\
\hline Brevibacillus & $\begin{array}{c}\text { Phylum Firmicutes } \\
\text { Order Bacillales } \\
\text { Family Paenibacillaceae }\end{array}$ & 18.5 \\
\hline Bacillales & Phylum Firmicutes, Order Bacillales & 11.6 \\
\hline Thermaceae & $\begin{array}{c}\text { Phylum Deinococcus-Thermus, } \\
\text { Order Thermales }\end{array}$ & 7.5 \\
\hline Elioraea tepidiphila & $\begin{array}{l}\text { Phylum Proteobacteria } \\
\text { Order Rhodospirillales }\end{array}$ & 3.7 \\
\hline Paenibacillus & $\begin{array}{l}\text { Phylum Firmicutes } \\
\text { Order Bacillales }\end{array}$ & 0.4 \\
\hline Bacillaceae & Phylum Firmicutes & 0.2 \\
\hline
\end{tabular}




\subsection{Isolation of PCL Degrading Bacteria}

Fourteen visibly different colonies isolated from MKC-P were sequenced and identified. They referred to four thermophilic species from three families, nine strains from Brevibacillus thermoruber (Paenibacillaceae), two strains from Aneurinibacillus thermoaerophilus (Paenibacillaceae), two strains from Geobacillus thermodenitrificans (Bacillaceae), and one strain from Meiothermus cateniformans (Thermaceae).

Pure strains were checked for a formation of clear zones around the colonies on agar plates in a basal medium with PCL as a sole carbon source (Figure 2). A good growth and halos were observed for B. thermoruber strain $7, A$. thermoaerophilus strain 2 and $M$. cateniformans strain 12. This result is in good agreement with the appearance of noticeable fractions of Brevibacillus and Meiothermus registered by the metagenomic analysis.

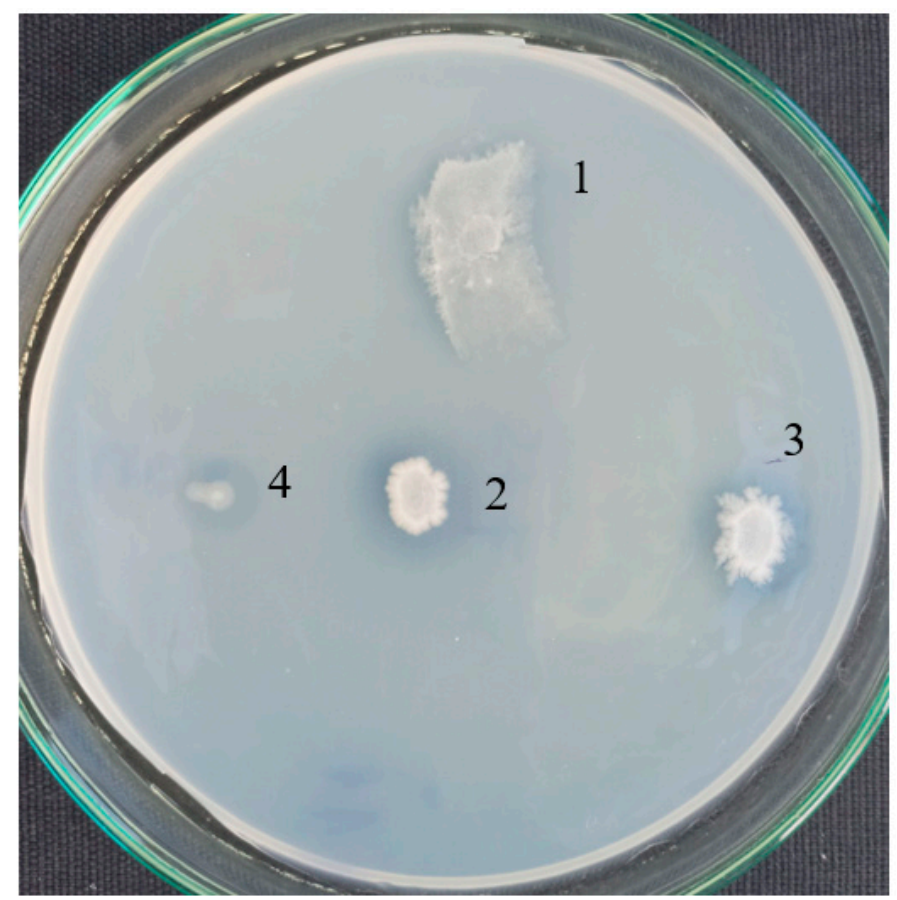

Figure 2. Clear halo by PCL-degrading bacteria isolated from Marikostinovo. 1, MKC-P; 2, Brevibacillus thermoruber strain 7; 3, Aneurinibacillus thermoaerophilus strain 2; 4, Meiothermus cateniformans strain 12.

The esterase assay confirmed quantitatively an activity for the three pure strains. The highest activity was measured for strain 7. Cells of strain 7 were deposited in NBIMCC (WDCM No. 135) under the number 9076 . Some moderate activity was observed for strain 2 and strain 12 (Table 3). Co-cultivation of strain 2 and strain 7 resulted in higher activity, while the esterase activity of co-cultures of strain 7 and strain 12 was even lower than that of strain 7 alone, determining the elimination of strain 12 from further experiments.

Table 3. Phylogenetic affiliation of the selected strains and esterase activity on $48 \mathrm{~h}$ of cultivation of the MKC-P and isolated strains alone and in a combination with B. thermoruber strain 7.

\begin{tabular}{cccc}
\hline $\begin{array}{c}\text { Highest-Homology Organism } \\
\text { (Maximum \% Identity of 16S } \\
\text { rRNA Gene Sequence) }\end{array}$ & Sequence Number & $\begin{array}{c}\text { Esterase } \\
\text { Activity of Pure } \\
\text { Strains (U/mL) }\end{array}$ & $\begin{array}{c}\text { Esterase Activity in } \\
\text { Co-Cultures (U/mL) } \\
\text { with B. thermoruber }\end{array}$ \\
\hline $\begin{array}{c}\text { Aneurinibacillus thermoaerophilus } \\
\text { strain 2 }\end{array}$ & MW927323 & 115 & 325 \\
Brevibacillus thermoruber strain 7 & MW541896 & 290 & - \\
Meiothermus cateniformans strain 12 & MW927332 & 42 & 70 \\
MKC-P & PRJNA766622 & & 375 \\
\hline
\end{tabular}




\subsection{Optimization of Physico-Chemical Parameters for PCL Degradation}

Optimization of the degradation conditions revealed highest esterase activity of MKC$\mathrm{P}$ and B. thermoruber strain 7 at $\mathrm{pH} 7.5-8.0$, while it was 8.0-8.5 for the co-culture of strain 7 and strain 2 . This result is in a good coincidence with the slightly alkaline $\mathrm{pH}$ of the spring water. The enzyme activity was enhanced with temperature reaching a maximum at $55^{\circ} \mathrm{C}$ for all variants. Temperature increases above $55^{\circ} \mathrm{C}$ resulted at plastic melting especially well, demonstrated at $65^{\circ} \mathrm{C}$ where an activity was not registered. Comparison among pNP palmitate (C16) and pNP caprylate (C8) as a substrate in the esterase assay revealed that activity with pNPP was 1.34-fold higher in the culture liquid from MKC-P and 1.2-fold higher in the case of strain 7.

The influence of the substrate concentration in the medium is shown on Figure 3. Highest enzyme levels were measured at PCL concentration of $0.3 \%, 375 \mathrm{U} / \mathrm{mL}$ for MKC-P, $290 \mathrm{U} / \mathrm{mL}$ for strain 7 , and $325 \mathrm{U} / \mathrm{mL}$ for co-culture of both pure strains.

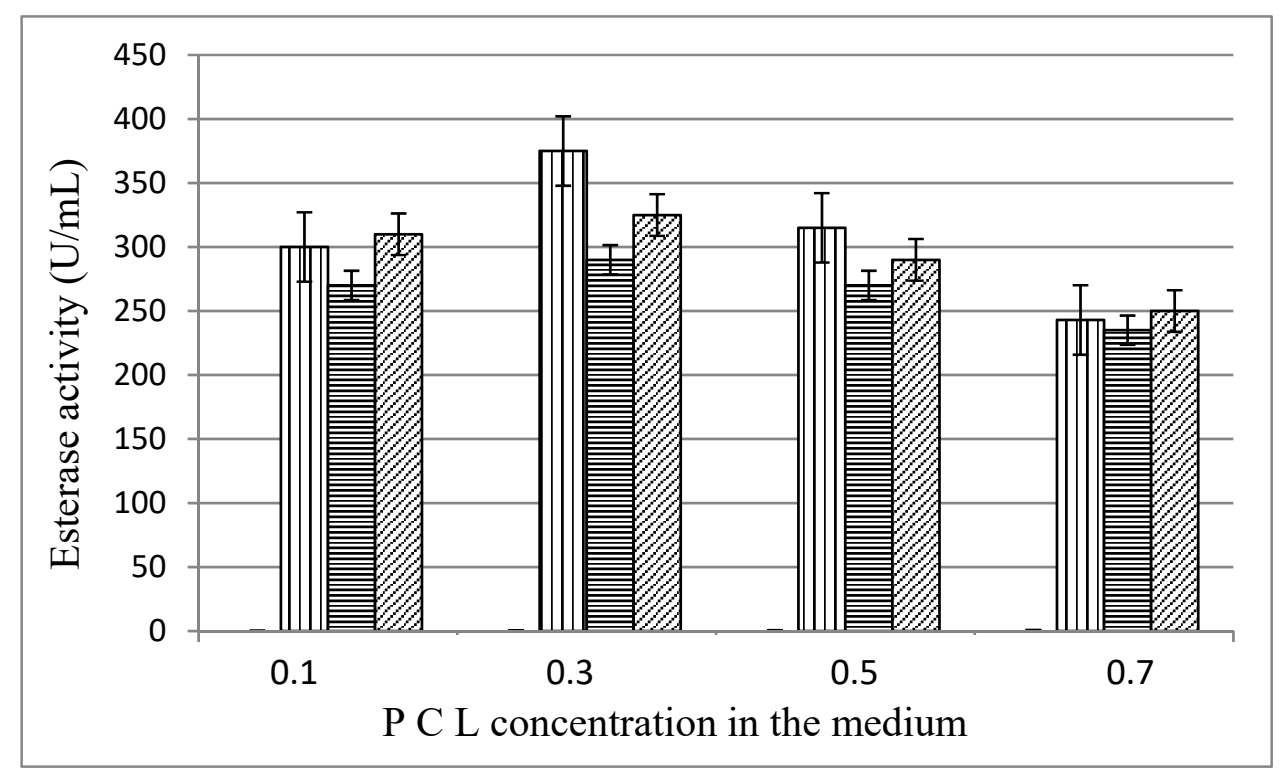

Figure 3. Esterase activity ( $48 \mathrm{~h}$ ) in different PCL concentration in the medium; IIII, MKC-P; 閭,

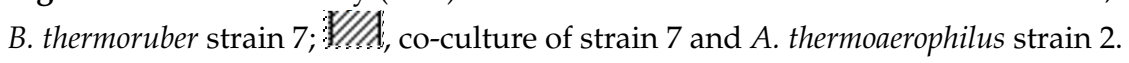

\subsection{Characteristics of PCL Biodegradation Process}

The extent of biodegradation of $0.3 \%$ PCL (Mw 80,000) by MKC-P, strain 7 , and coculture of strain 7 and strain 2 was followed for 4 weeks in liquid culture at $55^{\circ} \mathrm{C}, 80 \mathrm{rpm}$ (Table 4).

Full degradation of PCL and lack of flake traces was observed after four weeks in the presence of MKC-P, while the gravimetric weight loss was $63.6 \%$ in the case of strain 7 alone and $74.9 \%$ by the co-culture of strain 7 and strain 2 . The constant PCL weight in the control flasks demonstrated a lack of self-degradation throughout the experiment. A fast degradation rate with a maximum of $8.83 \mathrm{mg} / \mathrm{d}$ was observed at the beginning of the process by MKC-P, while the highest levels of $\sim 4 \mathrm{mg} / \mathrm{d}$ were measured at the second part of the process when pure strains were used. At the end of the first week the highest activity of $375 \mathrm{U} / \mathrm{mL}$ was measured in the culture liquid for MKC-P, the lowest activity $290 \mathrm{U} / \mathrm{mL}$ for strain 7 and an average activity of $325 \mathrm{U} / \mathrm{mL}$ for the co-culture and showed a slight tendency for a decrease during that time. The enzyme was extracellular as it was not found in cell debris. The difference in enzyme activity among the variants was not as significant as the degradation rate was and the higher efficiency of the degradation process by MKC-P was explained with the biofilm formation that posed microorganisms and substrate in a close vicinity. Cell concentration determined as a protein in the biofilm was the highest in MKC-P, reaching 7.3-fold higher levels in comparison with the other two samples. The 
low protein concentration in the adherent cells from strain 7 and co-culture with strain 2 suggested that these two strains were not main participants in the biofilm formation.

Table 4. Efficiency of PCL degradation by MKC-P, B. thermoruber strain 7, and B. thermoruber strain $7+$ A. thermoaerophilus strain 2.

\begin{tabular}{|c|c|c|c|c|c|c|c|c|c|}
\hline \multirow[b]{2}{*}{ Microorganisms } & \multirow[b]{2}{*}{ Week } & \multirow[b]{2}{*}{$\begin{array}{c}\text { Final } \\
\text { Weight }\end{array}$} & \multirow{2}{*}{$\begin{array}{c}\text { Weight Loss } \\
\text { per } 7 \text { Days } \\
\text { (mg) }\end{array}$} & \multirow{2}{*}{$\begin{array}{c}\text { PCL } \\
\text { Degradation } \\
\text { Rate }(\mathrm{mg} / \mathrm{d})\end{array}$} & \multirow{2}{*}{$\begin{array}{c}\text { Weight } \\
\text { Loss per } \\
\text { 7 Days (\%) }\end{array}$} & \multicolumn{3}{|c|}{ Protein Contents $(\mathrm{mg} / \mathrm{mL})$} & \multirow{2}{*}{$\begin{array}{c}\text { Esterase } \\
\text { Assay } \\
\text { U/mL }\end{array}$} \\
\hline & & & & & & $\begin{array}{l}\text { Protein in } \\
\text { Free Cells }\end{array}$ & $\begin{array}{l}\text { Protein in } \\
\text { Biofilms }\end{array}$ & $\begin{array}{c}\text { Total } \\
\text { Protein }\end{array}$ & \\
\hline Control & 4 & $150 \pm 9$ & 0 & 0 & 0 & 0 & - & 0 & 0 \\
\hline \multirow{4}{*}{ Community } & 1 & 88.2 & 61.8 & 8.83 & 41.2 & 0.23 & 1.31 & 1.54 & 375 \\
\hline & 2 & 48.8 & 39.4 & 5.63 & 26.3 & 0.45 & 1.56 & 2.01 & 375 \\
\hline & 3 & 20.1 & 28.7 & 4.1 & 19.1 & 0.63 & 1.39 & 2.02 & 333.8 \\
\hline & 4 & 0 & 20.1 & 2.87 & 13.4 & 0.17 & 0.84 & 1.01 & 291.6 \\
\hline \multirow{4}{*}{$\begin{array}{l}\text { B. thermoruber } \\
\text { strain } 7\end{array}$} & 1 & 134.7 & 15.3 & 2.18 & 10.2 & 0.75 & 0.05 & 0.80 & 290 \\
\hline & 2 & 115.2 & 19.5 & 2.78 & 13 & 0.78 & 0.15 & 0.93 & 290 \\
\hline & 3 & 84.2 & 31.0 & 4.42 & 20.6 & 0.84 & 0.19 & 1.03 & 258 \\
\hline & 4 & 54.5 & 29.7 & 4.24 & 19.8 & 0.11 & 0.14 & 0.25 & 125 \\
\hline \multirow{4}{*}{$\begin{array}{l}\text { B. thermoruber } \\
\text { strain } 7+A \text {. } \\
\text { thermoaerophilus } \\
\text { strain } 2\end{array}$} & 1 & 125 & 25 & 3.57 & 16.7 & 0.82 & 0.13 & 0.95 & 325 \\
\hline & 2 & 96.8 & 28.2 & 4.02 & 18.8 & 1.06 & 0.19 & 1.25 & 308 \\
\hline & 3 & 67.6 & 29.2 & 4.17 & 19.5 & 1.18 & 0.19 & 1.37 & 280 \\
\hline & 4 & 37.7 & 29.9 & 4.27 & 19.9 & 0.72 & 0.17 & 0.89 & 248 \\
\hline
\end{tabular}

The degradation rates in a process with lower PCL concentration of $0.1 \%$ were followed. Measured values were $9.96 \mathrm{mg} / \mathrm{d}$ for the first week, $6.65 \mathrm{mg} / \mathrm{d}$ for the second week, 4.42 for the third week and the whole process finished a week earlier for MKC-P. Consequently, a three-fold decrease in PCL concentration up to $0.1 \%$ resulted in only $\sim 10 \%$ increase in the maximal degradation rate. Similar were the values for strain $7(2.67,3.15$, 5.2, and 4.4, respectively). The degradation rate in experiments with PCL Mw 14,000) was $10.24 \mathrm{mg} / \mathrm{d}$ for first week; $7.5 \mathrm{mg} / \mathrm{d}$ for the second week; 3.69 for third week and at the end of the fourth week no PCL flakes were observed. These values were similar to the values when PCL Mw 80,000 was used.

Penetration chromatography analysis of PCL intermediates revealed a different elution pattern for MKC-P, strain 7 and co-culture of strain 7 and strain 2 that was especially well demonstrated on $48 \mathrm{~h}$ of cultivation (Figure 4). A peak corresponding to the molecular weight of 14,000 representing the original PCL (Figure 4A, Control) added to the culture medium appeared in the elution volume of $18.45 \mathrm{~mL}$ in strain 7 and co-culture of strain 7 and strain 2 samples, however with a different share- $83.74 \%$ for strain 7 and $54.99 \%$ for the co-culture. In the supernatant from strain 7 , the only additional peak was with an elution volume of $27.06 \mathrm{~mL}$ that corresponded with the monomer $\varepsilon$-caprolactone $(14.99 \%)$. In the co-culture of strains 7 and 2, three other peaks with elution volumes of 24.39, 25.13, and $26.93 \mathrm{~mL}$ were observed, corresponding of intermediates with a molecular weight of hexamer $(22.78 \%)$, trimer $(3.67 \%)$, and monomer $(4.25 \%)$ (Figure $4 \mathrm{~B})$. In the supernatant from MKC-P, PCL peak was almost not observed and the registered peaks with elution volumes $23.82 \mathrm{~mL}$ and $25.79 \mathrm{~mL}$ corresponded with 12 -mer $(8.2 \%)$ and dimer $(91.7 \%)$. The characteristic peaks in the elution profiles of the three samples were very similar for the samples from $72,96,120$, and $168 \mathrm{~h}$ of cultivation.

\subsection{SEM Investigations}

The changes in the plastic surface were confirmed by SEM. Control samples showed that the surface of the PCL pearls was not completely smooth (Figure 5A) and contained some wrinkles and deformations. No apparent effect of incubation duration was noted. Cultivation of $B$. thermoruber strain 7 for $72 \mathrm{~h}$ resulted in the occurrence of small bubble-like elevations on the surface of PCL pearls (Figure 5B) and shallow deformations (Figure 5C,D), which did not differ considerably from deformations present on the control pearls (Figure 5A). Adherent bacterial cells measuring c.a. $1.1 \times 0.6 \mu \mathrm{m}^{2}$ were only occa- 
sionally present (Figure 5D). The 3-week cultivation in the presence of strain 7 resulted in significant changes of PCL appearance which expand throughout the pearls surface. Characteristic was the formation of shallower (Figure 5E,F) or deeper (Figure 5G,H) infolds. The presence of adherent bacteria was still only occasional (Figure 5H), which implies that the dramatic changes on the PCL surface were much more likely due to the release of active bacterial products in the culture medium and not to biofilm formation.
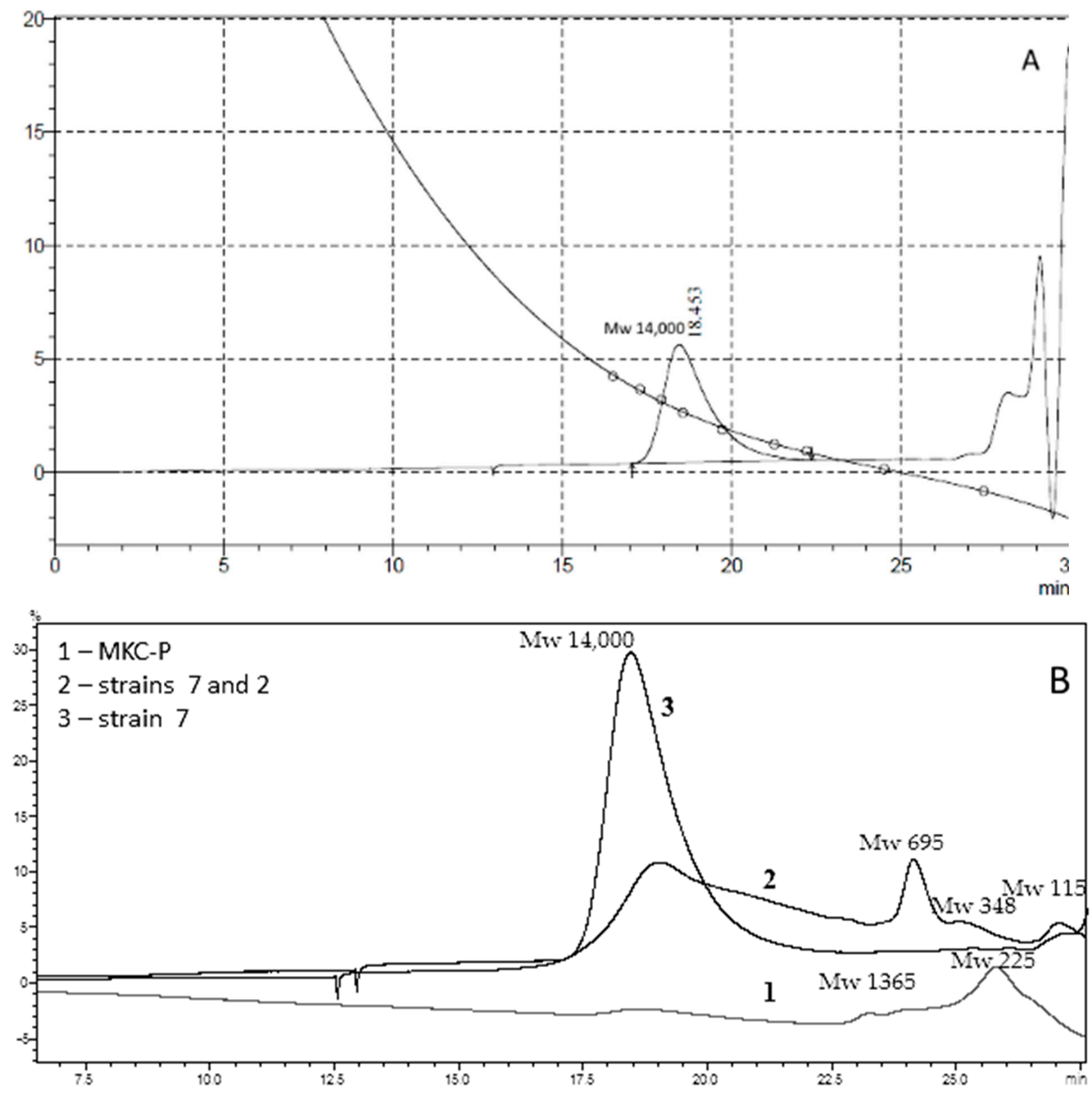

Figure 4. GPC elution pattern of PCL degradation intermediates on $48 \mathrm{~h}$ of cultivation. (A), Control-pure PCL; (B), 1, MKC-P; 2, co-culture of B. thermoruber strain 7 and A. thermoaerophilus strain 2; 3, B. thermoruber strain 7. 



Figure 5. Changes of the surface of PCL pearls cultivated in the presence of Brevibacillus thermoruber strain 7. (A), control. (B-D), cultivation in the presence of the strain for $72 \mathrm{~h}$. Deformations of the PCL surface comprise bubble-like elevations $(\mathbf{B}, \mathbf{C})$, single adherent bacteria are occasionally observed (D). (E-H), cultivation in the presence of the strain 7 for 3 weeks. The PCL surface is characterized by shallower $(\mathbf{E}, \mathbf{F})$ or deeper $(\mathbf{G}, \mathbf{H})$ infolds, with low incidence of attached bacteria (H, arrow). 
The SEM picture of the PCL cultivated in the presence of the bacterial community differed substantially from the one for the single strain. At the earlier tested interval of $72 \mathrm{~h}$, foci of adherence of bacterial cells (Figure 6A,B) were observed, and the development of biofilm microcolonies (Figure 6C,D) was frequent. At least three different morphotypes of bacteria were present in the microcolonies. They were distinct in width, length and the width to length ratio. The first type had a size of $(1.05 \pm 0.13) \times(0.63 \pm 0.10)$, length/width ratio 1.6 (Figure 6G) and were morphologically similar to those of strain 7 (Figure 5D). They represented $25 \%$ of all measured cells. The second type was the most abundant (68\%), with a size of $(1.45 \pm 0.29) \times(0.45 \pm 0.05)$, length/width ratio 3.22 (Figure $6 \mathrm{G}-\mathrm{I})$. Only a few bacteria with the third type of registered morphology were visible in the biofilm. They were pear-shaped cells, with a size of $(1.07 \pm 0.12) \times(0.45 \pm 0.02)$, length/width ratio 2.4 and represented 7\% of the measured cells (Figure 6I). On week 3, the incidence of significantly deformated loci did not considerably increase in comparison with the 72-h interval. Part of the bacteria tended to be submerged under the surface of the plastic pearl. Grainy structures appeared and bacterial cells were submerged under the grain-like debris (Figure 6J,K). This grainy material could be composed of the extrapolymeric substance of the biofilm, with a possible contribution of undecomposed plastic fragments.



Figure 6. Biofilm formation on the surface of PCL pearls cultivated in the presence of the bacterial community. (A-F), 72-h of cultivation. Adherence of bacterial cells (A,B), formation of microcolonies $(\mathbf{C}, \mathbf{D})$ and an apparent penetration of bacteria into the plastic (E,F) is illustrated. (G-I) Biofilm bacteria with three distinct types of morpholiogy were present on the PCL pearls: (1) oval cells morphologically similar to those of B. thermoruber strain 7 (Figure 5D); (2) rod-like cells; (3) pyriform bacteria. $(\mathbf{J}, \mathbf{K})$. On week 3 areas with the presence of grain-like material predominated, and the bacterial cells were submerged under this material (K, arrows). 


\section{Discussion}

During initial enrichment of MKC in the basal medium, a low growth (OD660) was observed for both MKC-P and MKC-C, however a formation of a colored biofilm on the plastic surface in PCL presence as a carbon source was visible. Metagenomic analysis of the two samples revealed that the biodiversity in MKC-P was lower (7 taxonomic groups) than that of MKC-C (11 taxonomic groups). Thermophilic Proteobacteria representatives dominated in MKC-C. Proteobacteria presence is universal for the environmental samples [28]. Its significant reduction from $81.2 \%, 7$ phylogenetic groups in MKC-C to $3.7 \%$, only one species in MKC-P resulted in flourishing of Meiothermus and Brevibacillus in MKC-P that suggested an active participation of these genera in the degradation process. Similar domination of polymer-active taxa in plastic containing samples has been reported for some marine communities [29,30]. Unfortunately, a comparison among the composition of thermophilic communities with and without plastic is not possible due to the lack of such information.

Fourteen pure strains were isolated on rich medium petri dishes after enrichment in the basal medium with PCL. Among them three strains demonstrated esterase activity, two belonged to an order Bacillales and one to an order Thermales. The isolation of two PCL degrading bacilli supported the opinion that thermophilic members of the family Bacillaceae are a good source of bacteria for bioprocessing and biotransformation [20]. The strain with the highest activity was identified as belonging to the species Brevibacillus thermoruber and was designated as a primary degrading microorganism and represented the first member of bacilli group able to degrade PCL. The genus Brevibacillus is known as an object of great biotechnological interest [31], however up to now only its activity toward low density polyethylene (LDPE) has been reported. The thermophilic bacterium B. borstelensis has been able to degrade $11 \%$ of polyethylene for 30 days [19]. B. borstelensis has not been good in the biofilm formation unlike another LDPE degrader B. parabrevis [32]. During the first week of cultivation of the strain 7 with PCL, low degradation rate of the plastic was registered, and together with this SEM analysis did not show considerable adherence of bacteria on the PCL pearls. As the rate of plastic degradation as a rule is low, it is not necessarily a presence of the primary degrader in high cell numbers. This could explain the lower concentration of Bacillaceae (among which is strain 7) in comparison with Meiothermus established in MKC-P by the metagenomic analysis. Such a low concentration of the primary degrader Streptomyces thermonitrificans PDS-1 was observed in the simultaneous cultivation with Bacillus licheniformis HA1 as a degrader of the intermediates [22]. The domination of Meiothermus could suggest its participation mainly in biofilm formation and/or in the utilization of the degradation intermediates. It is possible that not all microorganisms in the community involved in plastic degradation were detected and/or cultivated.

The effective plastic degradation by thermophilic bacilli have been reported for Anoxybacillus rupiensis Ir3 growing very well on nylon 6 [20] and Geobacillus thermocatenulatus that has decreased the molecular weight of nylon 12 and 66 for 20 days [21]. The degradation process with Clostridium thermocellum resulted in $60 \%$ weight loss of $50 \mathrm{mg}$ amorphous PET film for 14-days reaching a degradation rate of $2.2 \mathrm{mg} / \mathrm{d}$ [33]. Thermobifida fusca has decreased an average Mw of PET with $50 \%$ for 3 weeks [34].

Several mesophilic bacteria have been reported as PCL degraders. Weight loss and surface erosion of PCL degraded by Bacillus subtilis has been observed after 14 days of cultivation [15]. Biodegradation of PCL by a mesophilic Bacillus sp. has been seen within 20 days of cultivation at $40{ }^{\circ} \mathrm{C}$ although some surface changes have been visible after 7 days [11]. The representatives of the genera Pseudomonas, Alcanivorax, and Tenacibaculum isolated from deep seawaters at Toyama and Kume, Japan have caused morphological changes of PCL fiber surface after week cultivation at $25^{\circ} \mathrm{C}$ [9]. The residual breaking strength of PCL fibers reached $0 \%$ after 9 months soaking in deep seawaters. Pseudomonas and Rhodococcus sp. along with two fungal strains have degraded PCL films up to 53\% $(w / w)$ in 30 days of incubation [35].

Previously reported thermophilic bacteria active on PCL have been related to the genus Streptomyces. Streptomyces degraders have been active at $40-50{ }^{\circ} \mathrm{C}$ and have had a terrestrial 
origin. Streptomyces thermonitrificans PDS-1 has been isolated from compost of the fishprocessing industry [22], and Streptomyces thermoviolaceus subsp. thermoviolaceus 76T-2 has been isolated from soil in Taiwan [23]. Strain 7 was isolated from a hot spring and showed the highest temperature for degradation $\left(55^{\circ} \mathrm{C}\right)$, which is close to the melting temperature of PCL $\left(60^{\circ} \mathrm{C}\right)$ at which amorphous regions become soft and flexible. Unlike most of the reported mesophilic and thermophilic degraders, in our experiments visible changes in PCL surface were observed at $72 \mathrm{~h}$ of MKC-P and strain 7 cultivation. A comparatively fast degradation process with MKC-P and strain 7 and early visible changes in plastic surface confirmed that the isolate was among the most effective mesophilic and thermophilic PCL degraders isolated so far. The effectiveness of the biodegradation process was highest when MKC-P was used in comparison with strain 7 alone and co-cultures of strain 7 and strain 2 . The available information for the higher efficiency of plastic degradation by the microbial community in comparison with single isolates or a combination of two strains is scarce [36]. A microbial consortium isolated from plastic garbage processing areas has been significantly more effective in a gravimetric weight reduction and Mw reduction of LDPE than three pure strains isolated from the same consortium [37]. The gravimetric weight loss of PCL was $41.2 \%$ by MKC-P and $10.2 \%$ by strain 7 after seven-day process and $100 \%$ and $63.6 \%$ correspondingly after 4 -weeks. The highest degradation rate was $4.42 \mathrm{mg} / \mathrm{d}$ for strain 7 and $8.83 \mathrm{mg} / \mathrm{d}$ for MKC-P. MKC-P fully degraded $0.3 \%$ PCL for 4 weeks and $0.1 \%$ PCL for 3 weeks. An enhanced biodegradation potential by a combination of two bacterial species has been reported for Streptomyces thermonitrificans PDS-1 and Bacillus licheniformis HA1 [22]. S. thermonitrificans PDS-1 has been established to be responsible for primary PCL degradation in a fermentor seeded with raw compost materials, while B. licheniformis HA1 has had no primary degradation capability for PCL and its oligomers. The degree of PCL decomposition has been only $5 \%$ by the action of PDS- 1 alone, and $16 \%$ of the mixed culture containing both thermophiles. A synergistic effect has been suggested as a reason for the accelerated PCL degradation that has involved the consumption of $\varepsilon$-caprolactone by the coexistent microorganism promoting the growth of the primary degrader. The presently investigated combined use of strain 7 and strain 2 resulted in only a $10 \%$ increase in the degraded polymer, probably as a result of the simultaneous action of enzymes by both organisms, but not as a synergistic effect of degradation. The effectiveness of the degradation process by MKC-P and strain 7 at different PCL concentration did not differ significantly in the presence of $0.1 \%$ compared with that at $0.3 \%$ PCL. Although a strong dependence of the plastic degradation process from its molecular weight is commonly accepted [4] probably the insignificant difference in the case of PCL ( $\mathrm{Mw} 14,000$ and 80,000) was connected with the fact that an increase in its molecular weight resulted in an increase of the amorphous regions [16].

Gel penetration chromatography analysis gave evidence that MKC-P is the most effective in PCL degradation as PCL did not accumulate in the supernatant but was assimilated by the community members. The monomer ( $\varepsilon$-caprolactone) was also not detected, suggesting that it was consumed by an organism in the community. Registration of the monomer in the supernatant from strain 7 suggested that this microorganism was unable to assimilate $\varepsilon$-caprolactone or its assimilation was slower than its liberation from the PCL molecule. The registered monomer suggested that ester bonds are scissored at the ends of the polymer chain and the enzyme from this strain is an exoenzyme. Appearance of variety of low molecular weight intermediates in the supernatant from the co-culture of strain 7 and strain 2 confirmed the suggestion that strain 2 synthesized enzyme(s) different from that of strain 7 that act close to the end of the polymer chain. Unlike our results Streptomyces thermonitrificans PDS-1 has been reported as the only primary degrader, however its co-cultivation with Bacillus licheniformis HA1 has resulted in an accelerated PCL degradation and an increased deal of the decomposed polymer as HA1 has degraded the intermediates [22]. Esterases and particularly lipases were reported as main enzymes involved in the degradation of the polyester PCL $[4,38,39]$. Higher enzyme activity of MKC-P and strain 7 registered with pNP palmitate as a substrate than that with pNP 
caprylate suggested that the strain synthesized a lipase. Further detailed characterization of all enzymes included in the degradation process and the mechanism of their action is an object of a further work.

The highest degradation rate in flasks inoculated with the community in the early stage of the process could be explained by the presence of microorganism(s) that could contribute attachment to the plastic surface and biofilm formation. SEM results implied that this biofilm contained at least three different strains of bacteria. One of them was morphologically similar to the few cells, adherent to PCL in the sample treated with B. thermoruber strain 7 alone. As a single strain, strain 7 produced no biofilm, and could be characterized as adhesion deficient. However, the presence of the other stains in the community apparently increased its biofilm proficiency. Notably, cells of the "strain 7 morphotype" accounted for $25 \%$ of all bacteria in the biofilm formed by the community on hour 72 . This indicates that there could be synergistic interaction between the community strains in the colonization of the plastic surface. Synergistic interactions of this type have earlier been described for both laboratory strains in mixed biofilm experiments [40], and biofilms formed by natural consortia [41-43]. The stimulation of sessile growth of biofilm deficient strains could be accomplished by both cell-to-cell interactions [44] and released products of the adherence-proficient strains [45,46]. According to Pathak [4] the microbial heterogeneity of the biofilm matrix promotes fulfilling of nutrient requirements and poses in the close vicinity the substrate and the microorganisms. The close contact between the plastic and the microorganisms by biofilm formation is known to favor the biodegradation process [47]. The here observed further delay in the rate of degradation could be explained by the hindering of metabolite fluid through the biofilm. The late stage increase in the degradation rate in the presence of the pure strains confirmed the observation that strain 7 and strain 2 do not form a good biofilm and increased degradation was connected with the increase in cell numbers in the culture. Such a suggestion was also confirmed by the higher protein concentration in free cells in these variants in comparison with MKC-P. At the same time the protein measured in biofilms was several times higher in MKC-P. SEM investigations confirmed surface damage in all variants, however biofilm formation only in MKC-P.

\section{Conclusions}

Our study provided evidence for an effective PCL degradation by a thermophilic community and Brevibacillus thermoruber strain 7 isolated from the same community. For the first time, a representative of the most important biotechnological group, namely bacilli, was isolated in the current work as a PCL degrader. The optimal temperature for the degradation process was the highest among the so far reported for PCL degradation that caused favorable changes in plastic properties. The demonstrated high degradation rate by strain 7 defined it as one of the best PCL degraders described, and community's degradation rate was even higher. A possibility for full plastic degradation for four weeks by MKC-P and $63.6 \%$ by the pure strain and significant changes observed by SEM on the PCL surface suggested an effective application of the isolated community and the pure strain in plastic waste treatment.

Author Contributions: N.A. worked on inoculum preparation, cultivation, gravimetric analysis enzyme activity, and processed the experimental data; T.P.-K. worked on SEM investigations; S.S. aided in description and interpreting the SEM results, worked on the whole manuscript; N.R. and I.B. performed some laboratory analyses; K.P. worked on measuring Mw loss; M.K. conceived the experiments and wrote the manuscript. All authors have read and agreed to the published version of the manuscript.

Funding: This study was supported by the National Fund for Scientific Research, Bilateral Projects 2019-BULGARIA-RUSSIA (Grant KP-06-Russia-17).

Institutional Review Board Statement: Not applicable.

Informed Consent Statement: Not applicable. 


\section{Data Availability Statement: Not applicable.}

Conflicts of Interest: The authors declare no conflict of interest.

\section{References}

1. Plastics Europe. Plastics-The Facts 2020: An Analysis of European Plastics Production, Demand and Waste Data. 2020. Available online: https:/ / www.plasticseurope.org/application/files/3416/2270/7211/Plastics_the_facts-WEB-2020_versionJun21_final. pdf (accessed on 27 September 2021).

2. Polycaprolactone Market Analysis. Coherent Market Insights. 2020. Available online: https://www.coherentmarketinsights. com/market-insight/polycaprolactone-market-3553 (accessed on 28 April 2021).

3. Global Market Study on Polycaprolactone: Adoption of Biodegradable Polymers Enabling Increasing Usage of Polycaprolactone. Persistence Market Research. Available online: https://www.persistencemarketresearch.com/market-research/ polycaprolactone-market.asp (accessed on 28 April 2021).

4. Pathak, V.M. Review on the current status of polymer degradation: A microbial approach. Bioresour. Bioprocess. $2017,4,15$. [CrossRef]

5. Gajanand, E.; Soni, L.K.; Dixit, V.K. Biodegradable polymers: A smart strategy for today's crucial needs. Crit. Rev. Pharm. Sci. 2014, 3, 1-70.

6. Debroas, D.; Mone, A.; Ter Halle, A. Plastics in the North Atlantic garbage patch: A boat-microbe for hitchhikers and plastic degraders. Sci. Total Environ. 2017, 599-600, 1222-1232. [CrossRef]

7. Sivan, A. New perspectives in plastic biodegradation. Curr. Opin. Biotechnol. 2011, 22, 422-426. [CrossRef]

8. Tokiwa, Y.; Calabia, B.P.; Ugwu, C.U.; Aiba, S. Biodegradability of plastics. Int. J. Mol. Sci. 2009, 10, 3722-3742. [CrossRef]

9. Sekiguchi, T.; Saika, A.; Nomura, K.; Watanabe, T.; Fujimoto, Y.; Enoki, M.; Sato, T.; Kato, C.; Kanehiro, H. Biodegradation of aliphatic polyesters soaked in deep seawaters and isolation of poly ( $\varepsilon$-caprolactone)-degrading bacteria. Polym. Degrad. Stab. 2011, 96, 1397-1403. [CrossRef]

10. Oda, Y.; Oida, N.; Urakami, T.; Tonomura, K. Polycaprolactone depolymerase produced by the bacterium Alcaligenes faecalis. FEMS Microbiol. Lett. 1997, 152, 339-343. [CrossRef]

11. Motiwalla, M.J.; Punyarthi, P.P.; Mehta, M.K.; D'Souza, J.S.; Kelkar-Mane, V. Studies on degradation efficiency of polycaprolactone by a naturally occurring bacterium. J. Environ. Biol. 2013, 34, 43-49.

12. Abou-Zeid, D.M.; Muller, R.J.; Deckwer, W.D. Degradation of natural and synthetic polyesters under anaerobic conditions. J. Biotechnol. 2001, 86, 113-126. [CrossRef]

13. Pinto, M.; Langer, T.M.; Hüffer, T.; Hofmann, T.; Herndl, G.J. The composition of bacterial communities associated with plastic biofilms differs between different polymers and stages of biofilm succession. PLoS ONE 2019, 14, e0217165. [CrossRef]

14. Ahmed, T.; Shahid, M.; Azeem, F.; Rasul, I.; Shah, A.A.; Noman, M.; Hameed, A.; Manzoor, N.; Manzoor, I.; Muhammad, S. Biodegradation of plastics: Current scenario and future prospects for environmental safety. Environ. Sci. Pollut. Res. 2018, 25, 7287-7298. [CrossRef]

15. Balkova, R.; Hermanova, S.; Voberkova, S.; Damborsky, P.; Richtera, L.; Omelkova, J.; Jancar, J. Structure and morphology of microbial degraded poly ( $\varepsilon$-caprolactone)/graphite oxide composite. J. Polym. Environ. 2014, 22, 190-199. [CrossRef]

16. Balani, K.; Verma, V.; Agarwal, A.; Narayan, R. Physical, thermal, and mechanical properties of polymers. In Biosurfaces: A Materials Science and Engineering Perspective; John Wiley \& Sons, Inc.: Hoboken, NJ, USA, 2015; pp. 329-344. [CrossRef]

17. Kawai, F.; Kawabata, T.; Oda, M. Current knowledge on enzymatic PET degradation and its possible application to waste stream management and other fields. Appl. Microbiol. Biotechnol. 2019, 103, 4253-4268. [CrossRef] [PubMed]

18. Dang, T.C.H.; Dang, D.T.; Thai, H.; Nguyen, T.C.; Tran, T.T.H.; Le, V.H.; Nguyen, V.H.; Tran, H.B.; Pham, T.P.T.; Nguyen, T.G.; et al. Plastic degradation by thermophilic Bacillus sp. BCBT21 isolated from composting agricultural residual in Vietnam. Adv. Nat. Sci. Nanosci. Nanotechnol. 2018, 9, 015014. [CrossRef]

19. Hadad, D.; Geresh, S.; Sivan, A. Biodegradation of polyethylene by the thermophilic bacterium Brevibacillus borstelensis. J. Appl. Microbiol. 2005, 98, 1093-1100. [CrossRef]

20. Mahdi, M.S.; Ameen, R.S.; Ibrahim, H.K. Study on degradation of nylon 6 by thermophilic bacteria Anoxybacillus rupiensis Ir3 (JQ912241). Int. J. Adv. Res. Biol. Sci. 2016, 3, 200-209. [CrossRef]

21. Tomita, K.; Hayashi, N.; Ikeda, N.; Kikuchi, Y. Isolation of a thermophilic bacterium degrading some nylons. Polym. Degrad. Stab. 2003, 81, 511-514. [CrossRef]

22. Nakasaki, K.; Matsuura, H.; Tanaka, H.; Sakai, T. Synergy of two thermophiles enables decomposition of poly- $\varepsilon$-caprolactone under composting conditions. FEMS Microbiol. Ecol. 2006, 58, 373-383. [CrossRef]

23. Chua, T.K.; Tseng, M.; Yang, M.K. Degradation of Poly ( $\varepsilon$-caprolactone) by thermophilic Streptomyces thermoviolaceus subsp. thermoviolaceus 76T-2. AMB Express 2013, 3, e8. [CrossRef]

24. Atanasova, N.; Stoitsova, S.; Paunova-Krasteva, T.; Kambourova, M. Plastic degradation by extremophilic bacteria. Int. J. Mol. Sci. 2021, 22, 5610. [CrossRef]

25. Almeida, E.L.; Carrillo Rincón, A.F.; Jackson, S.A.; Dobson, A.D. In silico screening and heterologous expression of a polyethylene terephthalate hydrolase (PETase)-like enzyme (SM14est) with polycaprolactone (PCL)-degrading activity, from the marine sponge-derived strain Streptomyces sp. SM14. Front. Microbiol. 2019, 10, 2187. [CrossRef] 
26. Gupta, N.; Rathi, P.; Gupta, R. Simplified para-nitrophenyl palmitate assay for lipases and esterases. Anal. Biochem. 2002, 311, 98-99. [CrossRef]

27. Lowry, O.H.; Rosebrough, N.J.; Farr, A.L.; Randall, R.J. Protein measurement with the Folin phenol reagent. J. Biol. Chem. 1951, 193, 265-275. [CrossRef]

28. Zhou, Z.; Tran, P.Q.; Kieft, K.; Anantharaman, K. Genome diversification in globally distributed novel marine Proteobacteria is linked to environmental adaptation. ISME J. 2020, 14, 2060-2077. [CrossRef] [PubMed]

29. Dussud, C.; Meistertzheim, A.; Conan, P.; Pujo-Pay, M.; George, M.; Fabre, P.; Coudane, J.; Higgs, P.; Elineau, A.; Pedrotti, M.; et al. Evidence of niche partitioning among bacteria living on plastics, organic particles and surrounding seawaters. Environ. Pollut. 2018, 236, 807-816. [CrossRef]

30. Tourova, T.; Sokolova, D.; Nazina, T.; Grouzdev, D.; Kurshev, E.; Laptev, A. Biodiversity of microorganisms colonizing the surface of polystyrene samples exposed to different aqueous environments. Sustainability 2020, 12, 3624. [CrossRef]

31. Panda, A.K.; Bisht, S.S.; DeMondal, S.; Kumar, N.S.; Gurusubramanian, G.; Panigrahi, A.K. Brevibacillus as a biological tool: A short review. Antonie Van Leeuwenhoek 2014, 105, 623-639. [CrossRef]

32. Pramila, R.; Kesavaram, P.; Vijaya, R.; Krishnan, M. Brevibacillus parabrevis, Acinetobacter baumannii and Pseudomonas citronellolis-potential candidates for biodegradation of low density polyethylene (LDPE). J. Bacteriol. Res. 2012, 4, 9-14. [CrossRef]

33. Yan, F.; Wei, R.; Cui, Q.; Bornscheuer, U.T.; Liu, Y.J. Thermophilic whole-cell degradation of polyethylene terephthalate using engineered Clostridium thermocellum. Microb. Biotechnol. 2021, 14, 374-385. [CrossRef] [PubMed]

34. Müller, R.-J.; Schrader, H.; Profe, J.; Dresler, K.; Deckwer, W.-D. Enzymatic degradation of poly(ethylene terephthalate): Rapid hydrolyse using a hydrolase from T. fusca. Macromol. Rapid Comm. 2005, 26, 1400-1405. [CrossRef]

35. Urbanek, A.K.; Rymowicz, W.; Mirończuk, A.M. Degradation of plastics and plastic-degrading bacteria in cold marine habitats. Appl. Microbiol. Biotechnol. 2018, 102, 7669-7678. [CrossRef]

36. Ghosh, S.; Qureshi, A.; Purohit, H. Microbial degradation of plastics: Biofilms and degradation pathways. In Contaminants in Agriculture and Environment: Health Risks and Remediation; Agro Environ Media: Haridwar, India, 2019; Volume 1, pp. 184-199. [CrossRef]

37. Skariyachan, S.; Manjunatha, V.; Sultana, S.; Jois, C.; Bai, V.; Vasist, K.S. Novel bacterial consortia isolated from plastic garbage processing areas demonstrated enhanced degradation for low density polyethylene. Environ. Sci. Pollut. Res. Int. 2016, 23, 18307-18319. [CrossRef]

38. Yu, Y.; Li, H.; Zeng, Y.; Chen, B. Extracellular enzymes of cold-adapted bacteria from Arctic sea ice, Canada Basin. Polar Biol. 2009, 32, 1539-1547. [CrossRef]

39. Singh, P.; Singh, S.M.; Dhakephalkar, P. Diversity, cold active enzymes and adaptation strategies of bacteria inhabiting glacier cryoconite holes of High Arctic. Extremophiles 2014, 18, 229-242. [CrossRef]

40. Castonguay, M.H.; van der Schaaf, S.; Koester, W.; Krooneman, J.; van der Meer, W.; Harmsen, H.; Landini, P. Biofilm formation by Escherichia coli is stimulated by synergistic interactions and co-adhesion mechanisms with adherence-proficient bacteria. Res. Microbiol. 2006, 157, 471-478. [CrossRef] [PubMed]

41. Burmølle, M.; Webb, J.S.; Rao, D.; Hansen, L.H.; Sørensen, S.J.; Kjelleberg, S. Enhanced biofilm formation and increased resistance to antimicrobial agents and bacterial invasion are caused by synergistic interactions in multispecies biofilms. Appl. Environ. Microbiol. 2006, 72, 3916-3923. [CrossRef]

42. Ren, D.; Madsen, J.S.; Sørensen, S.J.; Burmølle, M. High prevalence of biofilm synergy among bacterial soil isolates in cocultures indicates bacterial interspecific cooperation. ISME J. 2015, 9, 81-89. [CrossRef]

43. Zupančič, J.; Raghupathi, P.K.; Houf, K.; Burmølle, M.; Sørensen, S.J.; Gunde-Cimerman, N. Synergistic Interactions in microbial biofilms facilitate the establishment of opportunistic pathogenic fungi in household dishwashers. Front. Microbiol. 2018,9 , 21. [CrossRef] [PubMed]

44. Uhlich, G.A.; Rogers, D.P.; Mosier, D.A. Escherichia coli serotype O157:H7 retention on solid surfaces and peroxide resistance is enhanced by dual-strain biofilm formation. Foodborne Pathog. 2010, 7, 935-943. [CrossRef]

45. Vacheva, A.; Ivanova, R.; Stoitsova, S. Stimulation of sessile growth of a biofilm-deficient strain Escherichia coli K-12 by protein(s) secreted by Enterobacteriaceae species. Biotechnol. Biotechnol. Eq. 2011, 25, 88-91. [CrossRef]

46. Vacheva, A.; Ivanova, R.; Paunova-Krasteva, T.; Stoitsova, S. Released products of pathogenic bacteria stimulate biofilm formation by Escherichia coli K-12 strains. Antonie Van Leeuwenhoek 2012, 102, 105-119. [CrossRef] [PubMed]

47. Ganesh, K.A.; Anjana, K.; Hinduja, M.; Sujitha, K.; Dharani, G. Review on plastic wastes in marine environment-Biodegradation and biotechnological solutions. Mar. Pollut. Bull. 2020, 150, 110733. [CrossRef] 